\title{
Key Plants in Fighting Cancer in the Middle East
}

\author{
Aref Abu-Rabia \\ Ben-Gurion University of the Negev, Beersheba, Israel \\ Email: arefabu@gmail.com
}

Received 15 February 2015; accepted 17 May 2015; published 20 May 2015

Copyright (C) 2015 by author and Scientific Research Publishing Inc.

This work is licensed under the Creative Commons Attribution International License (CC BY). http://creativecommons.org/licenses/by/4.0/

(c) (i) Open Access

\section{Abstract}

This article is derived from a broader study of ethno-botany, medical anthropology and alternative medicine in Middle Eastern countries, which has been conducted during the past two decades. It presents examples of different edible and medicinal plants and their uses by different communities (urban, peasant and Bedouin) in the treatment of diseases and various medical disorders. Alongside, the article reviews current knowledge concerning plants and cancer prevention and treatment. The article shows that people of these countries use various parts of the plant in a host of manners-fresh and soft, cooked or dried, as both food and medicine. These plants-part of the natural fauna of the Middle Eastern countries-grow in the wild and are cultivated. The author found that the most significant plants used were in the following families: Compositae, Gramineae, Labiatae, Lamiaceae, Liliaceae, Malvaceae, Oleaceae, Ranunculaceae, Umbelliferae, and Urticaceae.

\section{Keywords}

Medicinal Plants, Alternative Medicine, Cancer, Middle East

\section{Background}

Ancient Arab medicine was greatly influenced by medicinal practices in Persia, Mesopotamia, India, Greece, and Rome. The Greco-Roman system of medicine was based primarily on the writing of Hippocrates, Dioscorides, and Galen. The Arab system grew and developed during the rule of the Umayyad (661-750) and the Abbasids (750-1258). Ibn Sina (Avicenna 980-1037), who compiled the Canon of Medicine, and al-Razi (Rhazes 865-923), who compiled the Comprehensive Book on Medicine, were the most renowned Islamic physicians [1] [2].

Notably, the works of Ibn Sina and al-Razi were translated into Latin, and continued to influence medical work until as late as the nineteenth century [3] [4]. 
Most physicians in the Andalus (Islamic Spain) were herbalists. Among them was Ibn al-Baytar (1197-1248) whose Compendium of Simple Drugs and Food described more than 1400 medicinal drugs, including 300 not previously covered by other works [5]. The Arab medical tradition was established in the tenth century, developed in the eleventh and twelfth centuries, reached its peak from the thirteenth to the sixteenth centuries, and declined in the seventeenth to nineteenth centuries [6] [7]. Medical literature and healing methods that had been at the focus of traditional medicine for over a thousand years were marginalized by the advent of western medicine in the nineteenth and twentieth centuries, becoming the exclusive domain of traditional medicine and folk healers [7] [8]. Yet, the use of traditional medicine, particularly herbal medicine, was still widespread throughout the Middle East in the twentieth century, and remains so today [9] [10]. Most of the herbs used in herbal medicine serve both as food and as medications [11] [12].

\section{Introduction}

A famous Arab saying claims that "prevention is better than a cure", much like the old [Western] saying "an ounce of prevention is worth a pound of cure". Hippocrates, the father of medicine, recognizing the link between food and health, advised that "let your food be your medicine, and let your medicine be your food". The connection between diet and the risk of illness is apparent in the case of cancer. Cancer risk factors fall into two main categories: inherited and environmental. The considerable variation in dietary habits from culture to culture is widely accepted as a factor that underlies differences in cancer incidences in different populations around the globe [13] [14]. Inherited genetic defects are responsible for only about 15 percent of all cancers. This means that approximately 85 percent of all cancers result from environmental risk factors such as diet, lifestyle, and exposure to harmful substances [14]. The majority of cancers in humans are induced by carcinogenic factors present in our environment, including our diet.

Dietary influences have frequently been invoked to explain the marked variation in breast cancer incidence among racial and geographic groups [15]. The incidence of cancer overall in Mediterranean countries is lower than in Scandinavian countries and the United States, perhaps due to differences in diet. This difference is accounted for mainly by the lower incidence in Mediterranean countries of cancer of the large intestine, breast, endometrium, and prostate. Research shows that approximately one third of all cancer deaths are related to dietary factors and lack of physical activity in adulthood. There is increasing evidence that monounsaturated oils are associated with a lower risk of some cancers. This evidence is in line with the composition of olive oil and the potential role of monounsaturated fatty acids and minor compounds that are protective against reactive oxygen species [16].

The traditional Mediterranean diet is characterized by high consumption of plant foods, relatively low consumption of red meat, and high consumption of olive oil. The findings of studies in Italy, Spain, and Greece, suggest that olive oil may provide some protection against the development of breast cancer. Incidence rates of breast cancer in Mediterranean countries are relatively low compared with those in most other Western countries [17]. In a study assessing changes in diet and cancer mortality in Mediterranean countries, it was found that Greece and Spain had the lowest rates of ovarian cancer, the lowest intakes of animal fat and the highest consumption of olive oil [18]. It was reported that prostate cancer mortality in 32 countries was correlated with total fat consumption, although the association was not as strong as it was for breast cancer and appeared to be limited to animal fats. On the other hand, death rates from prostate cancer have been lower in areas with high olive oil consumption, such as Greece and Italy [19] [20]. A number of studies conducted in Mediterranean countries have reported inverse associations between olive oil consumption, on the one hand, and cancers of the stomach [21], lung [22], bladder [23], or urinary tract [24] on the other, even without controlling for energy intake.

Poor diet is a major cause of cancers in the United States. When diet is poor, the immune system is less able to defend the body against foreign invaders that can trigger the onset of cancer. In countries where people eat a Western diet, the rate of colorectal cancer is up to 10 times higher than that in countries where people follow an Asian diet [14].

The human body is designed to function efficiently by obtaining most of its energy and nutrition from plant sources [25]. In the absence of the important vitamins and minerals available in plant foods, the risk of cancer increases. Vegetables and fruits contain the anti-carcinogenic cocktail to which we are adapted [26].

The fact that many conventional drugs used in chemotherapy come from plants supports the use of natural medicines in treating cancers. Among these are vincristine and vinblastine from the periwinkle plant (Vinca mi- 
nor) and paclitaxel from the Pacific yew tree (Taxus brevifolin/Taxus brevifolia) [14].

Interestingly, some studies find that several herbs used in conjunction with conventional medicine can control and improve certain symptoms, such as fear and anxiety, better than medication alone and can support the social and psychological wellbeing of cancer patients and others [27].

\section{Methodology}

The data for this paper are derived from a broad study of ethno-botany and traditional medicine in the Middle East that took place over the course of two decades (in Palestine, Israel, Jordan, Sinai, and Egypt). The paper is based on interviews with healers and patients that were conducted using semi-structured questionnaires. All the data were recorded in field logs, and some were tape-recorded. The study included men and women of different ages and from a variety of groups. Plant samples were collected and identified by healers, elderly people, and university botanists. The samples were identified and classified according to the plants' leaves, flowers, barks, stems, stalks, roots, rhizomes, bulbs, tubers, fruits, corns, shells, seeds, stones/pits, soft seed pods, grain buds, shoots, twigs, oils, resins and gums, taste, and color.

\section{Results}

This article is derived from a broader study of ethno-botany, medical anthropology and alternative medicine in Middle Eastern countries. It presents examples of different edible and medicinal plants and their uses by different communities (urban, peasant and Bedouin) in the treatment of diseases and various medical disorders, as well as cancer prevention and treatment.

The article shows that peoples of these countries use various parts of the plant in a host of manners as both food and medicine. These plants parts are used fresh and soft, or cooked or dried. Toxic plants/bulbs are dried, boiled several times in water, or placed in hot ashes and then used for medicines or foods. The dosages for patients with the same diseases or disorders may vary, according to the ages and the structures of the patients' bodies.

Analysis of the findings shows that the Middle East is the geographic origin of both wild and cultivated medicinal plants. These plants may be picked in the wild or bought in specialty shops as well as from herbalists ('attarin).

The rich variety of approaches employed by different healers to treat or prevent cancer is indicative of the depth and breadth of indigenous medicine practiced among the Arab in the twentieth and twenty first centuries. It should be noted that wild desert plants also contain a host of other biologically active compounds besides nutrients. The physiological effects of these other compounds in relation to plant nutrients are not well known, but could affect nutrient and medical utilization or other functions. These topics are of relevance for future research in terms of improving our understanding of human nutritional and medical requirements of the people in the Middle East, especially with reference to cancer prevention and treatment.

Interviews results of the healers and patients are titled after Abu-Rabia 1993-2013, fieldwork notes.

The author found that the most significant plants that used are found in the following ten families as described below:

Compositae, Gramineae, Labiatae, Lamiaceae, Liliaceae, Malvaceae, Oleaceae, Ranunculaceae, Umbelliferae, and Urticaceae.

\section{Plants}

Warning: It is extremely important to note that in order to avoid side-effects, toxicity, or possible herb-drug interactions, caution should be exercised and all herbs should be taken only after consulting a physician or clinical herbalist.

\section{Compositae}

\section{Taraxacum cyprium $\mathrm{H}_{\text {. Lind }}$}

Arabic: salatat al-ruhban, handaba.

English: common dandelion.

Plant parts: whole herb, flowers, leaves, stems, and roots. 
Preparation: eat raw as a salad.

Active constituents: latex, bitter principles, alkaloids [28], vitamins A, B1, B2, B complex, and E, calcium, sodium, iron, potassium, phosphorus, chloride compound, and magnesium. The roots contain enzymes [29].

Properties and ethno-botanical uses: digestive, diuretic, tonic. It stimulates bile secretion and is used in the treatment of hepatic disorders, venereal diseases, herpes and other simple lip lesions, and piles. The flowers and leaves are eaten as a raw salad daily for one month to treat urinary retention and infections, renal stones, and hepatic disorders [11] [28]. The nuns and monks in Palestine's monasteries use the leaves and roots in green salad. It is also used to treat digestion problems and liver diseases, and may be pounded and boiled in water to treat cancerous tumors, anemia, acne, furuncles, and other skin conditions and tumors [30] [31]. Additionally, it is used to strengthen the bodies of infants and elderly people during and after recovery from disease [31]. The dandelion works against cancer by inducing apoptosis and differentiation, enhancing the immune system, inhibiting angiogenesis, and reversing multidrug resistance, and improves survival, increases tumor response and quality of life, and reduces chemotherapy toxicity [32].

\section{Gramineae}

\section{Avena sterilis L.}

Arabic: khafour, shufan, sha'ir al-hsayni.

English: oats.

Plant parts: seeds, hay and bran.

Active constituents: soluble fibers, proteins, unsaturated fatty acids, vitamins, niacin, and phytochemicals. Oat bran contains B complex vitamins, protein, fat, minerals, and heart-healthy soluble fiber called $\beta$-glucan, as well as magnesium, iron, copper, potassium, and selenium [33].

Properties and ethno-botanical uses: nutrient, diuretic, laxative, sedative, calmative, antispasmodic, and tonic. Water in which the seeds have been boiled is administered orally, to strengthen women after childbirth and to increase milk during breastfeeding. Seeds soaked in water are used as a cosmetic [30]. Oat seeds and hay are soaked in water to prepare a drink for the treatment of genitourinary tract infections, abdominal disorders, constipation, and diabetes, and to increase sexual desire. Oats are used to treat skin diseases, tumors, and cancer [11]. They also act as an antiseptic for the sexual organs of men and women and are used to treat prostate problems [31].

Various studies have shown that oats have the potential to prevent the appearance and progression of various conditions such as cancer, bowel malfunction, obesity, and celiac disease. Avena sativa has been reported as an antispasmodic and stimulant. It is used mainly for its nutritional value and is particularly beneficial in special diets for convalescents or for patients with illness such as gastroenteritis and dyspepsia [33]. Its dietary fiber complex, with its antioxidants and other phytochemicals, is effective against cardiovascular disease and some types of cancer [34]. Oats, like other grains and vegetables, contain hundreds of phytochemicals (plant chemicals), some of which are thought to possess cancer-preventive properties. Lignans, phytoestrogen compounds that are present in oats, have been linked to decreased risk of hormone-related diseases such as breast cancer [35], and similar effects are expected to be found regarding other hormone-related cancers such as prostate, endometrial, and ovarian cancers. International research has shown that women with a relatively high intake of dietary fiber have lower circulating estrogen levels, a factor associated with a reduced risk of breast cancer. The insoluble fibers in oats are also thought to reduce carcinogens in the gastrointestinal tract [36].

\section{Labiatae}

\subsection{Salvia officinalis L.}

Arabic: miramia, na'ema.

English: white sage.

Plant parts: leaves, seeds.

Active constituents: essential oil, tannin, camphor, cineol, borneol, pinene, resin [28], vitamin B complex, sulfur and steroid substances [29].

Ethno-botanical uses: antiseptic, astringent, antispasmodic, anti-inflammatory, gargle, emmenagogue, diuretic, cholagogue, infusion stimulant, tonic. Midwives used it to strengthen the uterus [28] [37]. Salvia officinalis es- 
sential oils and some identified terpenes inhibit human tumor cell growth [38]. Saliva officinalis oils inhibit human head and neck squamous cell carcinoma growth [39].

\subsection{Salvia fruticosa Mill}

Arabic: marmarya, miramia.

English: three-lobed sage, sage.

Plant parts: leaves and flowers.

Active constituents: essential oil, tannin, camphor cineol, borneol, pinene, resin [28], vitamin B complex [29]. The leaves contain essential oil, phenols, and thujone [10].

Properties and ethno-botanical uses: carminative, sedative. It is used to treat genitourinary tract infections, stomachache, diarrhea, open wounds, and nausea, and to regulate menstruation and ease menstrual pain [11] [31] [28]. It is also employed in the treatment of tumors, and stomach disturbances and administered to help women recover from miscarriage and after childbirth [31]. Other uses include the regulation of menstruation and treatment of urinary tract disorders [10]. It is also used to treat cancer [40]. Foods enriched with bioactive compounds, such as Salvia fruticosa Mill, have significant effects on health and represent a promising adjuvant treatment in patients with advanced breast cancer, due to their contribution in lowering the high oxidative stress present in these patients [41] [42].

\section{Lamiaceae}

\section{Origanum majorana L.}

Arabic: mardaddoush, mardaqoush, rayhan dawoud, za'ater.

English: sweet marjoram, knotted marjoram.

Plant parts: leaves.

Active constituents: ethanolic essential oil, linalool, and terpinen [43] [44].

Properties and ethno-botanical uses: Origanum majorana is used as an aphrodisiac, emmenagogue, tonic, hemorrhoid treatment, carminative, diuretic, and stimulant [37]. It is also used in the treatment of kidney stones, genitourinary tract infections, skin diseases, prostate, tumors and cancer as well as to strengthen the body and act as an appetizer [11] [40]. Among Arabs, marjoram (origanum) with olive oil is a favorite condiment [11]. Marjoram has been found to have potential anti-cancer (breast, colon, lung, pancreas, and prostate) effects [24] [45]. A comparative study between Arabs and Jews in Israel reveals that the striking differences in cancer prevalence are the result of different dietary patterns, which may include nutritional factors (like marjoram and olive oil) that serve as cancer-inducing or cancer-protective mechanisms [11]. Steam-distilled volatile oil from marjoram has been evaluated for its antibacterial and antifungal activities [46].

\section{Liliaceae}

\subsection{Allium cepa L.}

Arabic: basal.

English: onion.

Plant parts: leaves, bulb.

Preparation: fresh, dried, or cooked.

Active constituents: quercetin, glucokinin, pectin, essential oil [28]; vitamin C, potassium, phosphorus, sulfur, iron [29]; steroidal saponins and sapogenins [47] [48].

Properties and ethno-botanical uses: carminative, emmenagogue, aphrodisiac, hypoglycemic, appetizer [28]; antiseptic, and diuretic.

Onion may be squeezed onto the hands or into the mouth and nose to prevent influenza, colds, and other epidemic diseases. Fresh green onion leaves are eaten as salad or with other food. Eating leaves and bulbs is believed to treat genitourinary infections, increase sexual desire, and treat and prevent cancer [11] [49]. Onion is used to treat cancer in Palestinian traditional medicine [40]. Breast cancer risk was shown to decrease as consumption of onion increased, and consumption of onions is a risk reduction factor for prostate cancer mortality [50]. Onion is used to treat breast cancer [51], colorectal adenoma [52], gastric cancer [53], prostate [54], sto- 
mach, esophageal [55] and endometrial cancers [56].

\subsection{Allium sativum}

Arabic: thoum, thum.

English: garlic.

Plant parts: leaves and cloves.

Preparation: eat fresh leaves and cloves, or dried cloves.

Active constituents: alliin, essential oil, vitamins A, C, minerals [28], phosphorus, sulfur [29], alliin, allicin, garlic oil [57]-[60].

Properties and ethno-botanical uses: carminative, cholagogue, aphrodisiac, diuretic, and purgative [28]. Fresh green leaves/bulbs are eaten with salad. It is used to treat hemorrhoids, skin diseases, ulcers, kidney infections, intestinal worms, genitourinary infections, prostate and skin cancer, furuncles, and cancerous tumors [11] [40] [49].

Allium sativum (thoum) is added to the plants reported to augment natural killer (NK) cell activities, explaining and justifying the treatment of cancer patients with mixtures of these plant extracts. In many cases, there is marked improvement and, in some, complete cure [61]. Allium sativum was found to have several antimicrobial compounds, as well as active antitumor elements such allicin and ajoene [62] [63]. It has been reported that $\mathrm{Al}$ lium sativum enhances the anti-tumor activity of immune cells [64]. Tumor cells cover themselves with proteins rich in SH groups, thus preventing their destruction by the immune system. Ingestion of Allium sativum facilitates the destruction of tumor cells by blocking and/or oxidizing these SH groups [61].

\section{Malvaceae}

\section{Malva sylvestris $\mathrm{L}$}

Arabic: khubiza, khubaizih.

English: blue mallow.

Plant parts: leaves, seeds and flowers.

Preparation: eat as raw salad, cook, or boil in water and drink.

Active constituents: malvine, tannin, mucilage [28], sterols, terpenes [65].

Properties and ethno-botanical uses: the flowers are used as an expectorant and antitussive. The leaves are used as a laxative and emollient for the intestinal mucosa, totreat urinary tract diseases and vaginal infections, urinary retention and prostate illnesses, and skin irritation [28] [30].

The leaves have laxative properties and are used to treat night blindness. They are also used to treat tumors and cancer [11] [40]. The leaves and seeds increase breast milk production following childbirth. Blue mallow has nutritional value and is used as a tonic to increase sexual desire, mainly in the elderly. It is also used in the treatment of colds, cough, piles, and prostate problems (masour) [31].

\section{Oleaceae}

\section{Olea europaea $\mathrm{L}$.}

Arabic: zaytun, zayt.

English: olive tree, olive oil.

Plant parts: olive oil, fruit, and leaves.

Preparation: oil made from olives, olives cured for eating.

Active constituents: the composition of olive oil depends on the geographic location of the tree. Its components include olein, stearin, fixed oil, acids (palmitic and stearic) [28], vitamin E, and iron [29]. Olive leaves contain the glycoside oleuropein [10]. The oil of the fruit contains triglycerides (oleic, palmitic, linoleic, stearic and myristic acids; iridoid glycosides, oleuropein, and ligstroside). Olive stems containkaempferol, quercetin, esculentin, and esculin. The bark contains phenolic glucosides [58] [66].

Properties and ethno-botanical uses: The oil has nutritional value and is used as a laxative, tonic, lubricant, an emollient for skin and hair, a food, antiseptic, astringent, and febrifuge. Olive oil and a little salt may be rubbed over a baby's body to strengthen his bones and muscles and to prevent diaper rash [11] [40]. It is also used to treat venereal diseases, diabetes, prostate problems, kidney stones and infections [11] [40], and in cases of con- 
stipation, trachoma, gonorrhea, kidney stones, impaired virility, urinary retention, and urinary tract infection [28] [30].

Olive oil represents an important component of the Mediterranean diet [67] [68], which has been associated with some of the lower overall mortality patterns observed in large human populations. In Greece and Spain, long-time consumption of olive oil is associated with a decreased risk of breast cancer [69] [70]. It has been suggested that olive oil or olive oil-derived monounsaturated fat may have some absolute or relative protective effect on risk for breast and possibly other cancers [71] [17]. In Italy, the consumption of salad and vegetables containing olive oil is associated with a significantly reduced (34\% - 35\%) incidence of breast cancer compared to groups where olive oil is not consumed). These findings suggest that a diet rich in raw vegetables and olive oil protects against breast cancer [72]. Studies in Mediterranean countries revealed an inverse relation between consumption of olive oil and cancers of the bladder [23], stomach [21], urinary tract [24], and lung [22] [73].

Olive oil is the most widely used oil in Arab cuisine, and in several studies has been reported to offer some of its own protection against cancer compared to other forms of added lipids [14] [24]. In Italy, Buiatti et al. [21] found an inverse relation between gastric cancer and olive oil consumption; they suggest that vitamin E might contribute to this protective effect [74].

\section{Ranunculaceae}

\section{Nigella sativa L.}

Arabic: habbit al-barakah, habbih suda, qazhih.

English: Nigella, black cumin.

Plant parts: seeds or extracted oil.

Preparation: boil the seeds in water and drink, or drink the oil.

Active constituents: essential oil, fixed oil, nigellin, saponin [28], nigellimine N-oxide, and isoquinoline alkaloid [58] [75].

Properties and ethno-botanical uses: digestive, diuretic, emmenagogue, galactogogue, carminative [28] [37]. Black cumin is also used as a spice and to treat urinary tract infections and urinary retention, blood in the urine, diabetes, impotence, infertility, nausea and vomiting, prostate problems, tumors, ulcers, and furuncles. The oil extracted from the seeds is used to treat and prevent cancer and skin tumors [11] [30] [40] [49]). According to the Prophet Muhammad, it heals every illness. Its oil is beneficial for ophiasis, warts, and moles [76]. Nigella sativum is one of several plants reported to augment natural killer cell activities [77], so it has a potential role in cancer care [78]-[80].

\section{Umbelliferae}

\subsection{Coriandrum sativum L.}

Arabic: kuzbarah, kusbara.

English: coriander.

Plant parts: seeds and leaves.

Preparation: boil in water and drink.

Active constituents: essential oil, linalool, terpinene, corinadrol [28], and Vitamin C [29]. The essential oil of the fruit contains a high concentration (55\% - 74\%) of linalool, a material used in the production of vitamin A. The leaves of the plant are a source of vitamin A and vitamin C as well as coriander oil [10]. The fruit and leaves contain fats, proteins, and volatile oil [81]. The leaves contain caffeic acid, ferulic acid, gallic acid, and chlorogenic acid [82].

Properties and Ethno-botanical uses: stomachic, stimulant, pectoral, diuretic, antispasmodic, aphrodisiac [28]. Coriander is used by women after childbirth to strengthen the body and to increase milk production. It is also used to increase sexual desire and to treat urinary infections and prostate problems [11].

\subsection{Foeniculum vulgare Mill}

Arabic: shawmar.

English: fennel.

Plant parts: stems, leaves, and seeds. 
Preparation: boil leaves in water and drink two cups a day for three weeks. The green leaves of fennel are also eaten raw as a green salad and added to cooked food or to tea.

Active constituents: Essential oils including anethole, anisic acid, and fixed oil [28], potassium, and sulfur [29]. Fennel oil, anethole, enol, liquorice, and senna are produced from the fruit [10]. The seeds contain volatile oil; phenolic anethole, and fenchone, a ketone [61].

Properties and ethno-botanical uses: bronchodilator, antitussive, stimulant, diuretic, galactogogue, aphrodisiac, tonic and emmenagogue [28] [30]. It is also used to increase sexual passions and treatrenal infections [11] [40] and swollen breasts. Fennel is also used in the treatment of asthma, dizziness, nausea, vomiting, diarrhea, swelling of the stomach and abdomen, tonsillitis, sore throat, and oral infections. It is used to dissolve kidney stones and is employed in the treatment of constipation, obstructions of the urinary tract, trachoma, and infections of the sexual organs [31]. The seeds have nutritional value and are used as an appetizer and a sedative as well as to sweeten the breath. Foeniculum vulgare is among other medicinal herbs used in traditional Uighur medicine for the treatment and prevention of cancer, diabetes and cardiovascular diseases [83].

\section{Urticaceae}

\subsection{Urtica pilulifera L.}

Arabic: qurrais, hurriqi.

English: Roman nettle.

Plant parts: leaves, seeds, and roots.

Preparation: boil in water and drink.

Active constituents: glycoquinine, histamine, acids (silicic and formic), and tannin [28]; vitamins A and C, calcium, potassium, sulfur, and iron [29].

Properties and ethno-botanical uses: aphrodisiac, and diuretic. Fresh young leaves/roots are eaten to treat kidney stones and infections, rheumatism, female sterility, bleeding and cancer, intestinal pain and inflammation, liver disease, and bed wetting [11] [49], urinary tract infection and retention. It causes dermatitis upon contact [28]. It is supposed to be effective against cancer and prostate disorders [9] [40]. A diuretic is made by boiling the leaves drinking the liquid. This liquid is used to treat uterine bleeding [10] [30] [37].

\subsection{Urtica urens L.}

Arabic: qurrais, hurriqi.

English: large nettle.

Plant parts: young leaves.

Preparation: eat the fresh, young leaves.

Active constituents: glycoquinine, histamine, acids (silicic and formic), and tannin [28].

Properties and ethno-botanical uses: aphrodisiac, diuretic, styptic, antihemorrhagic, and galactogogue. It is used to treat kidney stones and infections, urinary retention, impotence, female sterility, sexual problems, rheumatism, and bleeding (to stop nose-bleed) [28] [37]. It causes dermatitis.

It has an antiproliferative effect on human prostate cancer cells [84], and induces adenosine deaminase inhibition in prostate tissue from cancer patients [85]. It may cause potential drug-herb interactions (including interaction with chemotherapy) [86].

\section{References}

[1] Hitti, P. (1952) History of the Arabs, from the Earliest Times to the Present. Macmillan \& Co. LTD, London.

[2] Ullmann, M. (1978) Islamic Surveys: Islamic Medicine. University Press, Edinburgh.

[3] Murad, A. (1966) Lamhat min tarikh al-tibb al-qadim = Glimpses from the History of Early Medicine. Maktabat alNasr al-Haditha, al-Qahira. (In Arabic)

[4] Al-Shatti, A. (1970) Al-'Arab waal-tibb = The Arabs and Medicine. Manshurat Wazarat al-Thaqafa, Dimashq. (In Arabic)

[5] Al-Najjar, A. (1994) Fi Tarikh al-Ttib fi al-Dawlah al-lslamyya: History of Medicine in the Islamic Empire. Dar alMa'aref, Al-Qahira. (In Arabic)

[6] Hamarneh, S. (1991) Ibn al-Quff's Contribution to Arab-Islamic Medical Sciences. Hamdard Medicines, 34, $27-36$. 
[7] Lev, E. (2002) Reconstructed material medica of the Medieval and Ottoman al-Sham. Journal of Ethnopharmacology, 80, 167-179. http://dx.doi.org/10.1016/S0378-8741(02)00029-6

[8] Lev, E. and Ammar, Z. (2000) Ethnopharmacological Survey of Traditional Drugs Sold in Israel at the End of the 20th Century. Journal of Ethnopharmacology, 72, 191-205. http://dx.doi.org/10.1016/S0378-8741(00)00230-0

[9] Ali-Shtayeh, M.S., Yaniv, Z. and Mahajna, J. (2000) Ethnobotanical Survey in the Palestinian Area: A Classification of the Healing Potential of Medicinal Plants. Journal of Ethnopharmacology, 73, 221-232. http://dx.doi.org/10.1016/S0378-8741(00)00316-0

[10] Palevitch, D. and Yaniv, Z. (2000) Medicinal Plants of the Holy Land. Modan Publishing House, Tel-Aviv, 104, 122, 205, 266-269.

[11] Abu-Rabia, A. (2005) Herbs as a Food and Medicine Source in Palestine. Asian Pacific Journal of Cancer Prevention, 6, 404-407.

[12] Abu-Rabia, A. (2014) Ethnobotany among Bedouin Tribes in the Middle East. In: Yaniv-Bachrach, Z. and Dudai, N., Eds., Medicinal and Aromatic Plants of the Middle East, Springer, Berlin, 27-36. http://dx.doi.org/10.1007/978-94-017-9276-9_3

[13] World Cancer Research/American Association for Cancer Research (1997).

[14] Murray, M., Birdsall, T., Pizzorno, J. and Reilly, P. (2002) How to Prevent and Treat Cancer with Natural Medicine. The Berkley Publishing Group, New York, 3-23, 89-99, 165.

[15] Lipworth, L., Martínez, M.E., Angell, J., Hsieh, C.C. and Trichopoulos, D. (1997) Olive Oil and Human Cancer: An Assessment of the Evidence. Preventive Medicine, 26, 181-190. http://dx.doi.org/10.1006/pmed.1996.9977

[16] Sergio, L., Yolanda M., P., Beatriz, B., et al. (2004) Olive Oil and Cancer. Grasas y Aceites, 55, 33-41.

[17] Cohen, L.A. and Wynder, E.I. (1990) Do Dietary Monounsaturated Fatty Acids Play a Protective Role in Carcinogenesis and Cardiovascular Disease? Medical Hypotheses, 31, 83-89. http://dx.doi.org/10.1016/0306-9877(90)90002-V

[18] Serra-Majem, L., La Vecchia, C., Ribas-Barba, L., et al. (1993) Changes in Diet and Mortality from Selected Cancers in Southern Mediterranean Countries, 1960-1989. European Journal of Clinical Nutrition, 47, S25-S34.

[19] Rose, D.P. and Connolly, J.M. (1992) Dietary Fat, Fatty Acids and Prostate Cancer. Lipids, 27, 798-803. http://dx.doi.org/10.1007/BF02535853

[20] Kushi, L.H., Lenart, E.B. and Willet, W. (1995) Health Implications of Mediterranean Diets in Light of Contemporary Knowledge. Meat, Wine, Fats and Oils. The American Journal of Clinical Nutrition, 61, 1416-1427.

[21] Buiati, E., Palli, D., Decarli, A., Amadori, D., Avellini, C. and Bianchi, S. (1989) A Case-Control Study of Gastric Cancer in Italy. International Journal of Cancer, 44, 611-616. http://dx.doi.org/10.1002/ijc.2910440409

[22] Fortes, C., Forastiere, F., Anatra, F. and Schmid, G. (1995) Consumption of Olive Oil and Specific Groups in Relation to Breast Cancer Risk in Greece. Journal of the National Cancer Institute, 87, 1020-1021. http://dx.doi.org/10.1093/jnci/87.13.1020-a

[23] Gonzalez, C.A., Torrent, M. and Agudo, A. (1990) Dietary Habits in Spain: An Approximation. Tumori, 76, 311 -314.

[24] Bitterman, W.A., Farhadian, H., Abu Samra, C., Lerner, D., Amoun, H., Krapf, D. and Makov, UE. (1991) Environmental and Nutritional Factors Significantly Associated with Cancer of the Urinary Tract Among Different Ethnic Groups. The Urologic Clinics of North America, 18, 501-508.

[25] Ryde, D. (1984) What Should Humans Eat? Practitioner, 232, 415-418.

[26] Steinmetz, K. and Potter, J. (1996) Vegetables, Fruit, and Cancer Prevention. Journal of the Academy of Nutrition and Dietetic, 96, 1027-1039. http://dx.doi.org/10.1016/S0002-8223(96)00273-8

[27] Gilbar, O., Iron, G. and Goren, A. (2001) Adjustment to Illness of Cancer Patients Treated by Complementary Therapy along with Conventional Therapy. Patient Education \& Counseling, 44, 243-249. http://dx.doi.org/10.1016/S0738-3991(00)00194-4

[28] Karim, F. and Qura'an, S. (1986) Medicinal Plants of Jordan. Yarmouk University, Irbid, 45, 68.

[29] Lust, J. (1980) The Herb Book. Bantam Books, Toronto \& New York, 501-508.

[30] Krispil, N. (2000) Medicinal Plants in Israel and throughout the World: The Complete Guide. Hed Arzi Publishing House, Or Yehuda, 226, 239.

[31] Abu-Rabia, A. (2013) Fieldwork Notes and Interviews with Healers, 1993-2013.

[32] Ruan, W., Mao-de, L. and Zhou, J. (2006) Anticancer Effects of Chinese Herbal Medicine, Science or Myth? Journal of Zhejiang University SCIENCE B, 7, 1006-1014.

[33] Chatuevedi, N., Yadav, S. and Shukla, K. (2011) Diversified Therapeutic Potential of Avena Sativa: An Exhaustive 
Review. Asian Journal of Plant Science and Research, 1, 103-114.

[34] Slavin, J., Marquart, L. and Jacobs, D.J. (2000) Cereal Food World. 45, 54-58.

[35] Limer, J.L. and Speirs, V., (2004) Phyto-Oestrogens and Breast Cancer Chemoprevention. Breast Cancer Research, 6, 119-127. http://dx.doi.org/10.1186/bcr781

[36] Guo, W., Nie, L., Wu, D., Wise, M., Collins, W., Meydani, S. and Meydani, M. (2010) Avenanthramides Inhibit Proliferation of Human Colon Cancer Cell Lines in Vitro. Nutrition and Cancer, 62, 1007-1016.

[37] Boulos, L. (1983) Medicinal Plants of North Africa. Reference Publications, Algonac, 110.

[38] Loizzo, M.R., Tundis, R., Menichini, F., et al., (2007) Cytotoxic Activity of Essential Oils from Labiatae and Lauraceae Families Against in Vitro Human Tumor Models. Anticancer Research, 27, 3293-3299.

[39] Sertel, S., Eichhorn, T., Plinkert, P.K. and Efferth, T. (2012) [Anticancer Activity of Saliva Officinalis Essential Oil against HNSCC Cell Line (UMSCC1)]. HNO, 59, 1203-1208.

[40] Ali-Shtayeh, M., Jamous, R. and Jamous, R. (2011) Herbal Preparation Use by Patients Suffering from Cancer in Palestine. Complementary Therapies in Clinical Practice, 17, 235-240. http://dx.doi.org/10.1016/i.ctcp.2011.06.002

[41] Drăgan, S., Nicola, T., Ilina, R., et al. (2007) Role of Multi-Component Functional Foods in the Complex Treatment of Patients with Advanced Breast Cancer. Revista Medico-Chirurgicală a Societăţii de Medici şI Naturalişsti din Iaşi, 111, 877-884.

[42] Duggan, C., Gannon, J. and Walker, W.A. (2002) Protective Nutrients and Functional Foods for the Gastrointestinal Tract. The American Journal of Clinical Nutrition, 75, 789-808.

[43] Charai, M., Mosaddak, M. and Faid, M. (1996) Chemical Composition and Antimicrobial Activities of Two Aromatic Plants: Origanum majorana L. and O. compactum Benth. Journal of Essential Oil Research, 8, 657-664. http://dx.doi.org/10.1080/10412905.1996.9701036

[44] Vági, E., Simándi, B., Suhajda, Á. and Héthelyi, É. (2005) Essential Oil Composition and Antimicrobial Activity of Origanum majorana L. Extracts Obtained with Ethyl Alcohol and Supercritical Carbon Dioxide. Food Research International, 38, 51-57. http://dx.doi.org/10.1016/j.foodres.2004.07.006

[45] Dursun, E., Otles, S. and Akcicek, E. (2004) Herbs as a Food Source in Turkey. Asian Pacific Journal of Cancer Prevention, 5, 334-339.

[46] Deans, S. and Svoboda, K. (2006) The Antimicrobial Properties of Marjoram (Origanum majorana L.) Volatile Oil. Flavour and Fragrance Journal, 5, 187-190.

[47] Salveron, M. and Cantonia, M. (1989) Phillipine-Grown Cultivars of Allium cepa. Planta Medica, 55, 662. http://dx.doi.org/10.1055/s-2006-962255

[48] Vollerner, Y., Abdullaev, N., Gorovits, M. and Abubakkirov, N. (1983) Steroidal Saponins and Sapogenins of Allium XVIII. The Structure of Karatavioside B. Khimiya Prirodnykh Soedinii, 2, 197-201.

[49] Zaid, H., Rayan, A., Said, O. and Saad, B. (2010) Cancer Treatment by Greco-Arab and Islamic Herbal Medicine. The Open Nutraceuticals Journal, 3, 203-212.

[50] Ben-Arye, E., Schiff, E., Hassan, E., et al. (2011) Integrative Oncology in the Middle East: From Traditional Herbal Knowledge to Contemporary Cancer Care. Annals of Oncology, 23, 211-221. http://dx.doi.org/10.1093/annonc/mdr054

[51] Challier, B., Perarnau, J.M. and Viel, J.F. (1998) Garlic, Onion and Cereal Fibre as Protective Factors for Breast Cancer: A French Case-Control Study. European Journal of Epidemiology, 14, 737-747. http://dx.doi.org/10.1023/A:1007512825851

[52] Millen, A.E., Subar, A.F., Graubard, B.I., et al. (2007) Fruit and Vegetable Intake and Prevalence of Colorectal Adenoma in a Cancer Screening Trial. The American Journal of Clinical Nutrition, 86, 1754-1764.

[53] Boeing, H., Jedrychowski, W., Wahrendorf, J., et al. (1991) Dietary Risk Factors in Intestinal and Diffuse Types of Stomach Cancer: A Multicenter Case-Control Study in Poland. Cancer Causes \& Control, 2, 227-233. http://dx.doi.org/10.1007/BF00052138

[54] Grant, W.B. (2004) A Multicountry Ecologic Study of Risk and Risk Reduction Factors for Prostate Cancer Mortality. European Urology, 45, 271-279. http://dx.doi.org/10.1016/j.eururo.2003.08.018

[55] Gonzalez, C.A., Pera, G., Agudo, A., et al. (2006) Fruit and Vegetable Intake and the Risk of Stomach and Oesophagus Adenocarcinoma in the European Prospective Investigation into Cancer and Nutrition (EPIC-EURGAST). International Journal of Cancer, 118, 2559-2566. http://dx.doi.org/10.1002/ijc.21678

[56] Galeone, C., Pelucchi, C., Dal Maso, L., et al. (2009) Allium Vegetables Intake and Endometrial Cancer Risk. Public Health Nutrition, 12, 1576-1579. http://dx.doi.org/10.1017/S1368980008003820

[57] Block, E., Saleem, A., Mahendra, J., Crecely, R., Apitz-Castro, R. and Cruz, M. (1984) The Chemistry of Alkyl Thio- 
sulphate Esters. 8. (E,Z)-Ajoene: A Potent Antithrombotic Agent from Garlic. Journal of the American Chemical Society, 106, 8295-8296. http://dx.doi.org/10.1021/ja00338a049

[58] Ghazanfar, S. and Al-Sabahi, A. (1993) Medicinal Plants of Northern and Central Oman. Economic Botany, 47, 89-98. http://dx.doi.org/10.1007/BF02862209

[59] McElnay, J.C. and Po, A.L.W. (1991) Dietary Supplements. 8. Garlic. Pharmaceutical Journal, 246, 324-326.

[60] Muller, B. (1990) Garlic (Allium sativum): Quantitative Analysis of the Tracer Substances Alliin and Allicin. Planta Medica, 56, 589-599. http://dx.doi.org/10.1055/s-2006-961198

[61] Abulafatih, H.A. (1987) Medicinal Plant of Southwestern Saudi Arabia. Economic Botany, 41, 354-360. http://dx.doi.org/10.1007/BF02859051

[62] Dirsch, V.M., Kiemer, A.K., Wagner, H. and Vollmar, A.M. (1988) The Effect of Allicin and Ajoene, Two Compounds of Garlic, on Inducible Nitric Oxide Synthase. Atherosclerosis, 139, 333-335. http://dx.doi.org/10.1016/S0021-9150(98)00094-X

[63] Singh, A. and Shukla, Y. (1998) Antitumor Activity of Diallyl Sulfide in Two-Stage Skin Model of Carcinogenesis. Biomedical and Environmental Sciences, 11, 258-263.

[64] Lipinski, B. and Egyud, L. (1992) Thiole Induced Cross-Linking of Human Blood Proteins: Implications for Tumor Immunity. Bioorganic \& Medicinal Chemistry Letters, 2, 919-924. http://dx.doi.org/10.1016/S0960-894X(00)80588-0

[65] Abbas, J.A., El-Oqlah, A.A. and Mahasneh, A.M. (1992) Herbal Plants in the Traditional Medicine of Bahrain. Economic Botany, 46, 158-163. http://dx.doi.org/10.1007/BF02930630

[66] Gariboldi, P., Jommi, G. and Verotta, L. (1986) Two New Secoiridoids from Olea europaea. Phytochemistry, 25, 865869. http://dx.doi.org/10.1016/0031-9422(86)80018-8

[67] Ferro-Luzzi, A. and Sette, S. (1989) The Mediterranean Diet: An Attempt to Define Its Present and Past Composition. European Journal of Clinical Nutrition, 43, 13-29.

[68] Trichopoulou, A. (1992) Composition of Greek Foods and Dishes (in Greek and English). Athens School of Public Health, Athens.

[69] Martin-Moreno, J.M., Willet, W.C., Gorgojo, L., Banegas, J.R., Rodriguez-Artalejo, F., Fernandez-Rodriguez, J.C., Maisonneuve, P. and Boyle, P. (1994) Dietary Fat, Olive Oil Intake and Breast Cancer Risk. International Journal of Cancer, 58, 774-780. http://dx.doi.org/10.1002/ijc.2910580604

[70] Trichopoulou, A., Katsouyanni, K., Stuver, S., Tzala, L., Gnardellis, C., Rimm, E. and Trichopoulous, D. (1995) Consumption of Olive Oil and Specific Food Groups in Relation to Breast Cancer Risk in Greece. Journal of the National Cancer Institute, 87, 110-116. http://dx.doi.org/10.1093/jnci/87.2.110

[71] Rose, D.P., Boyar, A.P. and Wynder, E.L. (1986) International Comparisons of Mortality Rates for Cancer of the Breast, Ovary, Prostate, and Colon and Per Capita Food Consumption. Cancer, 58, 1986, 2363-2371. http://dx.doi.org/10.1002/1097-0142(19861201)58:11<2363::AID-CNCR2820581102>3.0.CO;2-\#

[72] Sieri, S., Krogh, V., Pala, V., Muti, P., Micheli, A., Evangelista, A., Tagliabue, G. and Berrino, F. (2004) Dietary Patterns and Risk of Breast Cancer in the ORDET Cohort. Cancer Epidemiology, Biomarkers \& Prevention, 13, 567-572.

[73] Fortes, C., Forastiere, F., Farchi, S., Mallone, S., Trequattrinni, T., Anatra, F., Schmid, G. and Perucci, C.A. (2003) The Protective Effect of the Mediterranean Diet on Lung Cancer. Nutrition and Cancer, 46, 30-37. http://dx.doi.org/10.1207/S15327914NC4601 04

[74] Passmore, R. and Eastwood, M.A. (1986) Fats. In: Passmore, R. and Eastwood, M.A., Eds., Davidson and Passmore: Human Nutrition and Dietetics, Churchill Livingstone, Edinburgh, 55-58.

[75] Atta-ur-Rehman, M., Sohail, M., Jon, C., et al. (1985) Isolation and Structure Determination of Nigellicine, a Novel Alkaloid from the Seeds of Nigella sativa. Tetrahedron Letters, 26, 2759-2762. http://dx.doi.org/10.1016/S0040-4039(00)94904-9

[76] al-Jawziyya, I.Q. (1998) Medicine of the Prophet. The Islamic Texts Society, Cambridge. (Translated and Edited by Penelope Johnstone)

[77] Shen, R.N., Lu, L., Jia, X.Q., Wong, M.L. and Kaiser, H.E. (1996) Naturin: A Potent Bio-Immunomodifier in Experimental Studies and Clinical Trials. In Vivo, 10, 201-209.

[78] El-Obeid, A., Al-Harbi, S., Al-Jomah, N. and Hassib, A. (2006) Herbal Melanin Modulates Tumor Necrosis Factor Alpha (TNF-Alpha), Interleukin 6 (IL-6) and Vascular Endothelial Growth Factor (VEGF) Production. Phytomedicine, 13, 324-333.

[79] Abuharfeil, N.M., Maraqa, A. and Von Kleist, S. (2000) Augmentation of Natural Killer Cell Activity in Vitro against Tumor Cells by Wild Plants from Jordan. Journal of Ethnopharmacology, 71, 55-63. http://dx.doi.org/10.1016/S0378-8741(99)00176-2 
[80] Salim, E.I. and Fukushima, S. (2003) Chemo Preventive Potential of Volatile Oil from Black Cumin (Nigella sativa L.) Seeds against Rat Colon Carcinogenesis. Nutrition and Cancer, 45, 195-202. http://dx.doi.org/10.1207/S15327914NC4502_09

[81] Potter, T. and Fagerson, I. (1990) Composition of Coriander Leaf Volatiles. Journal of Agriculture and Food Chemistry, 38, 2054-2056. http://dx.doi.org/10.1021/jf00101a011

[82] Papai, et al. (2005) Encyclopedia of Agriculture and Food Systems. e-book, 473-481.

[83] Kizaibek, M., Kopp, B., Prinz, S., Popescu, R. and Upur, H. (2009) Antiproliferative Activity of Individual Herbs of Abnormal Savda Munziq on HL-60 Cells. Science \& Technology Review, 19, 94-98.

[84] Konrad, L., Muller, H.H., Lenz, C., et al. (2000) Antiproliferative Effect on Human Prostate Cancer Cells by a Stinging Nettle Root (Urtica dioica) Extract. Planta Medica, 66, 44-47. http://dx.doi.org/10.1055/s-2000-11117

[85] Durak, I., Biri, H., Devrim, E., et al. (2004) Aqueous Extract of Urtica Dioica Makes Significant Inhibition on Adenosine Deaminase Activity in Prostate Tissue from Patients with Prostate Cancer. Cancer Biology \& Therapy, 3, 855-857. http://dx.doi.org/10.4161/cbt.3.9.1038

[86] Agus, H.H., Tekin, P., Bayav, M. and Semiz, A.S. (2009) A Drug Interaction Potential of the Seed Extract of Urtica urens L. (Dwarf Nettle). Phytotherapy Research, 23, 1763-1770. http://dx.doi.org/10.1002/ptr.2848 